\title{
Effect of humidity on nitric acid uptake to mineral dust aerosol particles
}

\author{
A. Vlasenko $0^{1,3}$, S. Sjogren ${ }^{2}$, E. Weingartner ${ }^{2}$, K. Stemmler ${ }^{1}$, H. W. Gäggeler ${ }^{1,3}$, and M. Ammann ${ }^{1}$ \\ ${ }^{1}$ Laboratory of Radio- and Environmental chemistry, Paul Scherrer Institute, Villigen, Switzerland \\ ${ }^{2}$ Laboratory of Atmospheric Chemistry, Paul Scherrer Institute, Villigen, Switzerland \\ ${ }^{3}$ Department of Chemistry and Biochemistry, University of Bern, Bern, Switzerland
}

Received: 14 October 2005 - Published in Atmos. Chem. Phys. Discuss.: 18 November 2005

Revised: 20 March 2006 - Accepted: 20 April 2006 - Published: 20 June 2006

\begin{abstract}
This study presents the first laboratory observation of $\mathrm{HNO}_{3}$ uptake by airborne mineral dust particles. The model aerosols were generated by dry dispersion of Arizona Test Dust (ATD), $\mathrm{SiO}_{2}$, and by nebulizing a saturated solution of calcium carbonate. The uptake of ${ }^{13} \mathrm{~N}$-labeled gaseous nitric acid was observed in a flow reactor on the $0.2-$ $2 \mathrm{~s}$ reaction time scale at room temperature and atmospheric pressure. The amount of nitric acid appearing in the aerosol phase at the end of the flow tube was found to be a linear function of the aerosol surface area. $\mathrm{SiO}_{2}$ particles did not show any significant uptake, while the $\mathrm{CaCO}_{3}$ aerosol was found to be more reactive than ATD. Due to the smaller uncertainty associated with the reactive surface area in the case of suspended particles as compared to bulk powder samples, we believe that we provide an improved estimate of the rate of uptake of $\mathrm{HNO}_{3}$ to mineral dust. The fact that the rate of uptake was smaller at a concentration of $10^{12}$ than at $10^{11}$ was indicative of a complex uptake mechanism. The uptake coefficient averaged over the first $2 \mathrm{~s}$ of reaction time at a concentration of $10^{12}$ molecules $\mathrm{cm}^{-3}$ was found to increase with increasing relative humidity, from $0.022 \pm 0.007$ at $12 \% R H$ to $0.113 \pm 0.017$ at $73 \% R H$, which was attributed to an increasing degree of solvation of the more basic minerals. The extended processing of the dust by higher concentrations of $\mathrm{HNO}_{3}$ at $85 \% \mathrm{RH}$ led to a water soluble coating on the particles and enhanced their hygroscopicity.
\end{abstract}

\section{Introduction}

Heterogeneous interactions between atmospheric trace gases and aerosols are important in several issues of atmospheric chemistry. The processing of atmospheric particles might affect the chemical and physical properties of the aerosol; on

Correspondence to: $\mathrm{M}$. Ammann

(markus.ammann@psi.ch) the other hand, it may also impact the global budget of important trace gas compounds. Among the many potential reactions occurring, the reaction of mineral dust aerosol with $\mathrm{HNO}_{3}$ might be very important as it affects the ozone budget of the upper troposphere, because there the photolysis of $\mathrm{HNO}_{3}$ is a significant source of $\mathrm{NO}$ and $\mathrm{NO}_{2}$, to which ozone sensitively responds (Bauer et al., 2004; Bian and Zender, 2003; Dentener et al., 1996).

The heterogeneous reactions of mineral dust particles are also of significant interest because they could change the particle surface properties, which can therefore affect the properties of dust as cloud condensation or ice nuclei. The importance of this issue on a global scale has been demonstrated by several modelling studies (Kärcher and Lohmann, 2003; Lohmann et al., 2004). Laskin et al. (2005b) reported field evidence of complete, irreversible processing of particles containing solid calcium carbonate and quantitative formation of liquid calcium nitrate particles, apparently as a result of the heterogeneous reaction of calcium carbonate with gaseous nitric acid. Such conversion of insoluble material to soluble material strongly affects the radiative properties of these aerosol particles as well as their ability to act as cloud condensation nuclei. Recent ambient studies have shown the ability of Saharan dust aerosol particles to form ice crystals in cirrus clouds (DeMott et al., 2003; Sassen et al., 2003). Currently, the question to what degree processing of dust particles by trace gases affects heterogeneous ice nucleation is subject of laboratory and field investigations (Archuleta et al., 2005).

Mineral dust is a complex mixture of different minerals, and its reactivity with trace gases obviously depends on the composition. To understand the mechanism of the heterogeneous interaction with dust one could study the reactions with each of the components. However, the reactive behaviour of complex mixtures is not only a superposition of the behaviour of their individual components. In addition, in practice it would be a hard task to complete due to the

Published by Copernicus GmbH on behalf of the European Geosciences Union. 


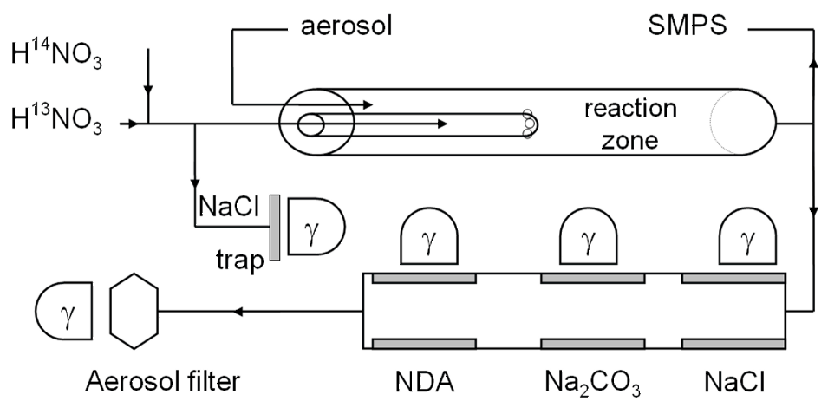

Fig. 1. Schematic diagram of the flow reactor and detection system.

complexity of the dust composition. Therefore, in the case of $\mathrm{HNO}_{3}$, many studies have concentrated on identifying the most reactive components, among which is $\mathrm{CaCO}_{3}$, and assessing their reactivity (Fenter et al., 1995; Goodman et al., 2001; Hanisch and Crowley, 2001; Krueger et al., 2004; Frinak et al., 2004). In the present work, the heterogeneous reactivity of $\mathrm{CaCO}_{3}$ and $\mathrm{SiO}_{2}$ has been compared to the reactivity of the Arizona Test Dust (ATD) aerosol particles. These components are chosen since quartz is one of the major (by weight) constituent of the dust in general and in the ATD in particular; and calcite is suggested to be one of the most reactive constituents of the dust (Usher et al., 2003). While many other studies focussed on Ca rich authentic dusts, ATD used in the present study is among the Ca poorer, though not less abundant forms of dust.

In this study, a dry dispersion generation method was used to produce submicron mineral dust aerosol and to measure the kinetics of the heterogeneous reaction with gaseous nitric acid with the aerosol particles in gas suspension. To our knowledge it is the first time that such a method was used for the production of a surrogate for atmospheric mineral dust in combination with a kinetic flow-tube technique. This approach is an alternative to the published studies of heterogeneous interactions in a Knudsen cell or with single particle techniques.

This study concentrates on basic uptake data and its dependence on relative humidity as well as the consequences on the hygroscopic properties of the dust particles. Ongoing, more detailed kinetic experiments will be reported elsewhere.

\section{Experimental}

The experimental method used is similar to the ones reported previously (Ammann, 2001; Guimbaud et al., 2002). Nitric acid labelled with a short-lived radioactive isotope ${ }^{13} \mathrm{~N}$ is mixed with the aerosol particles in a flow reactor. After a certain reaction time, gas phase and particulate phase products are separated and trapped in a parallel-plate denuder and in a filter, respectively. The concentration of each species is measured by counting the number of ${ }^{13} \mathrm{~N}$ decays in each trap per unit time. In this way, the loss of nitric acid from the gas phase and its irreversible uptake by the aerosol particle surface are measured simultaneously. The scheme of the setup is given in Fig. 1. Hygroscopic properties of dust particles were studied before and after $\mathrm{HNO}_{3}$ exposure in a separate reactor using a HTDMA system described below.

\subsection{Production of $\mathrm{HNO}_{3}$}

The production of ${ }^{13} \mathrm{~N}$ in the form of ${ }^{13} \mathrm{NO}$ has been described in detail elsewhere (Ammann, 2001). In brief, the ${ }^{13} \mathrm{~N}$ isotope is produced via the reaction ${ }^{16} \mathrm{O}(p, \alpha){ }^{13} \mathrm{~N}$ in a gas-target, which is set up as a flow cell, through which $20 \%$ $\mathrm{O}_{2}$ in He pass at $11 / \mathrm{min}$ stp at $2.5 \mathrm{~atm}$, and which is continuously irradiated by $15 \mathrm{MeV}$ protons provided by the accelerator facilities at Paul Scherrer Institute. The radiation chemistry in the target cell also leads to the production of non-labelled nitrogen oxides at around $30 \mathrm{ppbv}$ from nitrogen impurities in the carrier gas supplies. The primary ${ }^{13} \mathrm{~N}$ molecules and radicals, along with their non-labeled counterparts, are reduced to ${ }^{13} \mathrm{~N}$ labelled $\mathrm{NO}$ over a TiC catalyst immediately after the target cell. The resulting gas is continuously transported to the laboratory through a $580 \mathrm{~m}$ long capillary. There, a small fraction of this flow (typically $25 \mathrm{ml} / \mathrm{min}$ ) is mixed with nitrogen as carrier gas (1 lpm) in our experiments. Additional amounts of non-labelled NO can be added from a certified cylinder (10 ppm in $\mathrm{N}_{2}$ ) to vary the total concentration of $\mathrm{NO}$ within a range of $1 \mathrm{ppb}$ to $1 \mathrm{ppm}$. $\mathrm{NO}$ is oxidized to $\mathrm{NO}_{2}$ by reaction with ozone in a flow reactor with a volume of 21 . Ozone is generated by passing a mixture of synthetic air in nitrogen through a quartz tube irradiated by a mercury penray UV lamp $(185 \mathrm{~nm}$ wavelength). $\mathrm{HNO}_{3}$ is produced from the reaction of $\mathrm{NO}_{2}$ with $\mathrm{OH}$ radicals; the flow containing $\mathrm{NO}_{2}$ is humidified to $40 \%$ relative humidity and irradiated by a second $172 \mathrm{~nm}$ excimer UV lamp to produce $\mathrm{OH}$ radicals, which rapidly convert a large fraction of $\mathrm{NO}_{2}$ to $\mathrm{HNO}_{3}$ (see results section). The photolysis of the $\mathrm{H}_{2} \mathrm{O} / \mathrm{O}_{2} / \mathrm{N}_{2}$ mixture also leads to the formation of $\mathrm{HO}_{2}$ radicals and $\mathrm{O}_{3}$, the concentration of each of which depends on humidity, $\mathrm{O}_{2}$ content and light intensity (Aschmutat et al., 1994). We have optimized the $\mathrm{O}_{2}$ content to keep the $\mathrm{O}_{3}$ concentrations below $30 \mathrm{ppbv}$. We have not determined the degree of contamination by $\mathrm{H}_{2} \mathrm{O}_{2}$ resulting from radical radical reactions of $\mathrm{OH}$ and $\mathrm{HO}_{2}$.

\subsection{Aerosol particle generation}

In this study, two types of aerosol generation methods were employed: dry dispersion from a powder and atomisation of an aqueous solution. The dispersion of Arizona Test Dust and detailed characterisation of the resulting aerosol is published elsewhere (Vlasenko et al., 2005). Here only a short description of the technique is given. In a first step, the sample powder is dispersed by a solid aerosol generator (Topas $\mathrm{GmbH}$, Dresden, Germany). Therein, a special belt feeds the dust to an injector nozzle in order to provide a constant 
input. Shear forces created in the injector disperse and disaggregate the powder to form submicron particles. In a second step, the remaining coarse particles are removed by a cyclone and a virtual impactor. This method is used to produce submicron particles from Arizona Test Dust (Ellis Components, England) and silica (Aerosil 200, Degussa, Germany). Calcium carbonate aerosol was generated by nebulizing a saturated aqueous $\mathrm{CaCO}_{3}$ solution (Model 3075, TSI, USA). The resulting droplets are dried by passing the flow through a diffusion dryer. Charged particles from both aerosol sources are removed by passing the flow through an electrical precipitator. Finally, the aerosol flow is conditioned to a certain relative humidity. The humidifier is a vertically mounted tube with a $\mathrm{H}_{2} \mathrm{O}$ permeable Goretex membrane $(150 \mathrm{~mm}$ length, $6 \mathrm{~mm}$ i.d.) immersed in demineralised water. The relative humidity was measured by capacitance detectors at room temperature. The aerosol number concentration, size distribution and total aerosol surface area are measured by a Scanning Mobility Particle Sizer (SMPS, TSI, USA). The size spectra of the aerosols obtained are given in Fig. 2. One can see that the particle concentration was largest for silica aerosol and lowest for the calcium carbonate particles. As discussed in detail by Vlasenko et al. (2005), the SMPS system underestimates the total surface area of this aerosol due to lack of data for the size range above $800 \mathrm{~nm}$. We therefore performed several measurements using an optical particle counter (OPC, GRIMM Labortechnik GmbH, Germany, Model 1.108) as described by Vlasenko et al. (2005). A log-normal size distribution was then fitted to the combined SMPS and OPC data, normalized and then scaled to the actual spectrum obtained by an individual SPMS scan, when the SMPS was used on-line during the uptake experiments. This results in a reproducibly increased aerosol surface area by about $25 \%$ as compared to the surface area reported by the SMPS system alone (Vlasenko et al., 2005). All surface area data reported hereafter were corrected this way.

\subsection{Flow reactor for kinetic experiments}

Mineral dust aerosol and nitric acid flows are mixed to react in the flow tube reactor with cylindrical geometry. The reactor is a PFA Teflon tube of $8 \mathrm{~mm}$ inner diameter and $10 \mathrm{~mm}$ outer diameter. The PFA Teflon material has been chosen to minimise the losses and retention of $\mathrm{HNO}_{3}$ on the surface (Neuman et al., 1999). Gaseous nitric acid is introduced via an injector along the axis of the flow reactor. The injector is a PFA tube (i.d. $4 \mathrm{~mm}$ ), which could be moved along the axis of the reactor. The position of the injector determines the gas-aerosol contact or reaction time. When the injector is pushed all the way in to the maximum position inside the flow reactor then the reaction time is minimum $(0.2 \mathrm{~s})$ and vice versa $(2 \mathrm{~s})$. The end of the injector tube is supplied with a special plug so that the gas enters the flow reactor through small openings at the end of the injector, perpendicular to the flow of aerosol. This is used to facilitate rapid

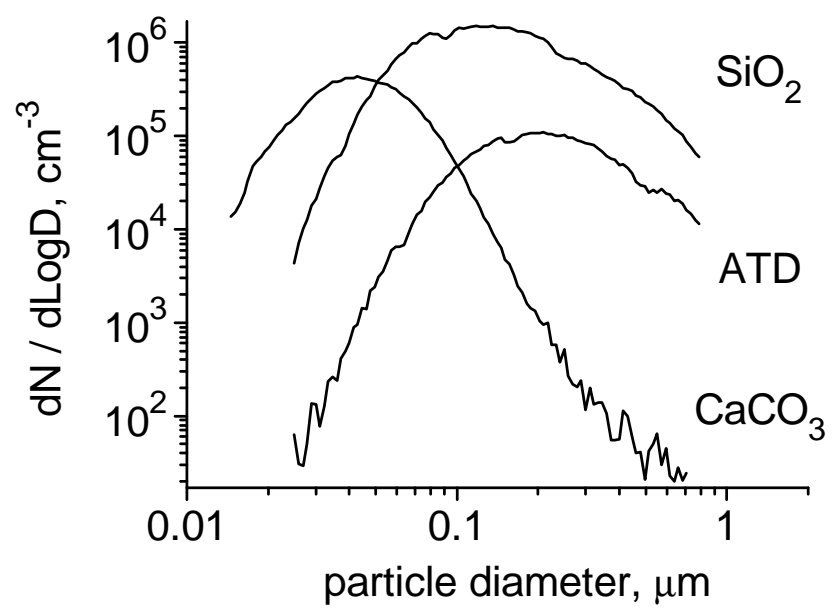

Fig. 2. Size distribution of aerosol particles used to study the heterogeneous reaction with gaseous nitric acid.

mixing of the flows, which is critical for exactly controlling the reaction time. The degree of mixing was checked by measurement of the aerosol particle concentration upstream and downstream of the injection point by extracting a small flow with a small capillary pushed in from the opposite end of the reactor. The particle concentration after the mixing with the gas flow was in accord with the calculated dilution factor after $0.2 \mathrm{~s}$ mixing time. The results of this test suggest that the flows are well mixed within $0.2 \mathrm{~s}$ contact time. The flow tube is operated under laminar flow conditions (Reynolds number $\sim 130$ ), and it is assumed that the laminar flow profile is established a few $\mathrm{cm}$ downstream of the injector. The outer flow tube is replaced after each 6 hours of operation to avoid wall losses of $\mathrm{HNO}_{3}$ driven by particles deposited on the inner wall. Note that due to the removal of charged particles prior to the flow reactor (see above) the loss of particles to the walls are strongly reduced. Nevertheless, it was observed that $\mathrm{HNO}_{3}$ was lost on the walls above the normal retention losses (see Sect. 3.3 below) after extensive exposure of the flowtube to aerosol particles. This led to the strict replacement schedule to avoid any effect of particles on the wall to the uptake on the aerosol. The system is kept at room temperature. The relative humidity of the flow is continuously measured downstream of the reactor.

\subsection{Detection system}

The flow leaving the flow reactor was directly entering the parallel-plate denuder system. The latter captures the gaseous species $\mathrm{HNO}_{3}, \mathrm{HONO}, \mathrm{NO}_{2}$ on different chemically selective coatings by lateral diffusion. Note that this denuder train also effectively scrubs $\mathrm{HNO}_{3}$ reversibly adsorbed to the particles. The sub-micron aerosol particles have a small diffusivity and pass through the denuder without being collected. Gaseous nitric acid is taken up in the first denuder section coated with $\mathrm{NaCl}$. HONO is collected in the next 
section coated with $\mathrm{Na}_{2} \mathrm{CO}_{3}$, while $\mathrm{NO}_{2}$ is absorbed in the third section by reaction with NDA (N-(1-naphtyl) ethylene diamine dihydrochloride) mixed with $\mathrm{KOH}$. These coatings are freshly prepared after each $6 \mathrm{~h}$ of operation. As mentioned above, generation of $\mathrm{HNO}_{3}$ by reaction of $\mathrm{NO}_{2}$ with $\mathrm{OH}$ is accompanied by ozone production under $\mathrm{UV}$ radiation. High concentrations of $\mathrm{O}_{3}$ are not desirable because ozone reacts with the NDA-coating and depletes the capacity of the coating to absorb $\mathrm{NO}_{2}$. As also mentioned above, the parameters were optimized to keep the output concentration of $\mathrm{O}_{3}$ at minimum (below $30 \mathrm{ppb}$ ). After passing the denuder, the aerosol particles are captured by a glass fiber filter. To each trap (the coatings and filter) a separate CsI scintillator crystal with integrated PIN diode was attached (Carroll and Ramsey, USA) which detects the gamma quanta emitted after decay of the ${ }^{13} \mathrm{~N}$ atoms. The detector signal is converted to the flux of the gaseous species into the trap using the inversion procedure reported elsewhere (Guimbaud et al., 2002; Kalberer et al., 1996; Rogak et al., 1991). This flux is proportional to the concentration of the species in the gas phase.

An additional NaCl-trap is used to monitor the concentration of gaseous $\mathrm{HNO}_{3}$ in a small side flow before entering the reactor. The trap consists of a quartz-fiber filter, soaked with a saturated aqueous $\mathrm{NaCl}$ solution and dried. Also to this trap, a scintillator device as that described above is attached. This measurement provides a "reference" for the generation of gaseous nitric acid and reduces the uncertainty related to the instability of the flux of ${ }^{13} \mathrm{~N}$ arriving in the laboratory. The relative counting efficiency of each detector is determined by accumulating a certain amount of $\mathrm{H}^{13} \mathrm{NO}_{3}$ in the "reference" trap and exposing it to each of the other detectors attached to the denuder sections and the particle filters in a way that closely mimics the geometrical configuration at each trap. The concentration of non-labelled $\mathrm{NO}$ and $\mathrm{NO}_{2}$ is monitored by a chemiluminescence analyser (Ecophysics, Switzerland). Further details of the preparation of the coatings, trap and filter efficiencies, and the performance of the detection system are published elsewhere (Ammann, 2001; Guimbaud et al., 2002).

2.5 Mineral dust processing and measurement of hygroscopic properties

Apart from the kinetic experiments, ATD aerosol particles were also processed by gaseous $\mathrm{HNO}_{3}$ in a laminar flowtube reactor at room temperature and atmospheric pressure over longer time scales. This flow reactor was a $88 \mathrm{~cm}$ long $3.9 \mathrm{~cm}$ inner diameter cylindrical Pyrex tube with the inner walls covered with Teflon PFA foil. The mean residence time of the aerosol in this reactor was $3 \mathrm{~min}$ at a flowrate of $0.3 \mathrm{lpm}$. Relative humidity in the reactor was monitored by a capacitance detector. To vary the relative humidity in the reactor chamber, the aerosol flow passes through the humidifier (identical to the one described above). The flow of $\mathrm{HNO}_{3}$ was maintained by passing a $0.2 \mathrm{lpm}$ flow of ni- trogen through a bubbler, which contained a nitric acid solution in $\mathrm{H}_{2} \mathrm{O}(0.1 \mathrm{M})$ at $12^{\circ} \mathrm{C}$. Half of this flow was directed to a molybdenum converter held at $400^{\circ} \mathrm{C}$ and then to a NO chemiluminescence detector to monitor the concentration of nitric acid in the gas phase (Joseph and Spicer, 1978). The concentration of gaseous $\mathrm{HNO}_{3}$ detected in this way was $3 \times 10^{13}$ molecules $\mathrm{cm}^{-3}$ at $298 \mathrm{~K}$. The other half of the $\mathrm{HNO}_{3}$ flow is mixed with the ATD aerosol flow $(0.2 \mathrm{lpm})$ prior to the reactor entrance. After the reaction chamber, the aerosol flow was drawn through a $\mathrm{NaOH}$ coated denuder tube to remove $\mathrm{HNO}_{3}$ from the gas phase. The hygroscopic properties of the processed ATD aerosol were measured by a Hygroscopicity Tandem Differential Mobility Analyzer (HTDMA) system described elsewhere (Weingartner et al., 2002). Briefly, in this instrument, the aerosol is first dried to a low $R H(<5 \%)$ and fed into the first differential mobility analyzer (DMA) where a monodisperse particle size fraction is selected (diameter $D=D_{o}$ ). Then, the aerosol is exposed to higher $R H$ over a period of $\sim 60 \mathrm{~s}$, and the resulting new particle size distribution is determined with a second DMA combined with a condensation particle counter. This instrument is capable of measuring the hygroscopic growth factor (GF) defined as the relative particle diameter increase from dry to humidified state, $D / D_{o}$. A prehumidifier $(R H=95 \%)$ is included or bypassed in order to measure hygroscopic growth factors during dehydration or hydration.

\section{Results and discussion}

\subsection{Procedure of the kinetic experiments}

The time profiles of the $\mathrm{NO}_{2}, \mathrm{HNO}_{3}(\mathrm{~g}), \mathrm{HNO}_{3}$ (g-reference) and $\mathrm{HNO}_{3}$ (aerosol) concentrations during an individual uptake experiment are illustrated in Fig. 3 and described in detail below.

The experiment starts with equilibrating the system by running all gas flows without the admission of ${ }^{13} \mathrm{~N}$-labelled nitrogen dioxide (0-12 min time interval). At this time the background signals of the gamma detectors are recorded.

Then at 12 min, a small flow of ${ }^{13} \mathrm{NO}_{2}$ is admitted to the main gas flow. The NDA coating of the denuder starts to absorb nitrogen dioxide from the gas phase, accompanied by an increasing number of decays observed in this trap (panel A, dashed line). This growing signal is inverted to the flux of ${ }^{13} \mathrm{~N}$ labelled molecules into this trap, which is proportional to the concentration of the ${ }^{13} \mathrm{NO}_{2}$ in the gas phase (panel $\mathrm{A}$, solid line). Because this flux is calculated based on the difference of two consecutive activity measurements only, the inverted data (solid line) show more apparent scatter than the raw activity signals (dashed line). Prior to the reactive absorption in the NDA-trap the nitrogen dioxide molecules travel along the $\mathrm{NaCl}$ and $\mathrm{Na}_{2} \mathrm{CO}_{3}$ traps. Due to reversible adsorption and some slow conversion to $\mathrm{HNO}_{3}$ and $\mathrm{HONO}$, some of the ${ }^{13} \mathrm{~N}$ atoms are also being absorbed on these traps, 
which leads to a small increase of the corresponding detector signals (panel B, solid line). For the same reason, the signal at the "reference" trap detector is increased (panel B, dashed line). The efficiency of the $\mathrm{NO}_{2}$ absorption in the NDA-trap is not entirely $100 \%$, so that a small fraction of $\mathrm{NO}_{2}$ may penetrate the denuder to the aerosol filter and manifests itself as a slight increase of the signal (panel C). Note that this penetrating fraction may be extremely low but may still allow a detectable signal.

At $33 \mathrm{~min}$ of the experiment, the production of $\mathrm{HNO}_{3}$ is started by switching on the UV lamp for $\mathrm{OH}$ production to convert $\mathrm{NO}_{2}$ into $\mathrm{HNO}_{3}$. As a result, the detector signal of the NDA-trap decreases by about a factor of three (panel A, solid line). It indicates that two thirds of the labelled $\mathrm{NO}_{2}$ molecules were oxidized to $\mathrm{HNO}_{3}$. We use this conversion factor to calculate the overall concentration of nitric acid in the gas phase by applying the same factor for the conversion of non-labelled $\mathrm{NO}_{2}$, the concentration of which is measured by the chemiluminescence detector. The increase of the $\mathrm{HNO}_{3}$ concentration is detected at the $\mathrm{NaCl}$ denuder (panel $\mathrm{B}$, solid line) and in the reference trap (panel B, dashed line).

The mineral dust particles are introduced to the flow reactor at $75 \mathrm{~min}$ of the experiment. The gas phase nitric acid concentration drops (panel B, solid line) due to reaction with the aerosol surface, while the concentration of the particulate $\mathrm{HNO}_{3}$ increases (panel C). As noted above, the signal associated with particulate $\mathrm{HNO}_{3}$ is due to $\mathrm{HNO}_{3}$ irreversibly taken up to the particles. $\mathrm{HNO}_{3}$ desorbing from the particles faster than $0.1 \mathrm{~s}$ would be detected as gas phase $\mathrm{HNO}_{3}$ in the first denuder. No increase of the signals in the other denuders has been observed during the presence of aerosol, so that not significant amounts of $\mathrm{HNO}_{3}$ desorbing on the time scale of a second while travelling along the denuder train had been associated with the aerosol. A significant loss of $\mathrm{HNO}_{3}$ from the particles on the filter on the time scale of minutes would have resulted in a lack of mass closure for $\mathrm{HNO}_{3}$.

Using the procedure given here, uptake to aerosol particles can be measured as a function of reaction time, $\mathrm{HNO}_{3}$ concentration in the flow tube and relative humidity. The algorithm to derive the value of the uptake coefficient from the measurements shown in Fig. 3 is described below.

\subsection{Calculation of the uptake coefficient}

The uptake coefficient is usually defined as the ratio between the net flux of molecules from the gas phase to the aerosol particles, $J_{\text {net }}$, and the gas-kinetic collision flux of the molecules to the surface of the particles, $J_{\text {coll }}$,

$\gamma=\frac{J_{\text {net }}}{J_{\text {coll }}}$

Defined this way, the uptake coefficient is a reasonable way to obtain a normalized quantity related to the rate of uptake observed in the experiment. In principle, the mechanism leading to the net transfer of $\mathrm{HNO}_{3}$ to an irreversibly bound

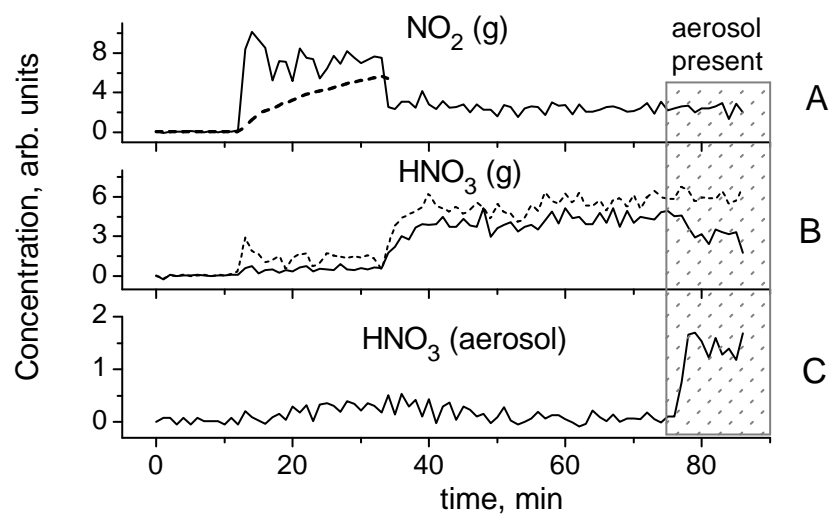

Fig. 3. Online record of an uptake experiment. Panel (A): dashed line represents the signal of $\gamma$-detector at the NDA-trap and solid line corresponds to the concentration of nitric dioxide. Panel (B): the dashed line represents the "reference" gas phase concentration of $\mathrm{HNO}_{3}$ (concentration before entering the reactor) and the solid line corresponds to the concentration after the reactor. Panel (C): the solid line represents the concentration of nitric acid on the aerosol surface. The grey bar (75-90 min) corresponds to the time when aerosol was present in the flow reactor. The $\mathrm{HNO}_{3}$ gas phase concentration in the flow tube was $10^{11} \mathrm{~cm}^{-3}$ and $R H 33 \%$.

product in the particulate phase can be very complex. Nevertheless, we are assuming a simple first order approach similar to that reported earlier (Guimbaud et al., 2002). Note that this approach assumes a constant (quasi-steady state) uptake to the aerosol during the residence time of the aerosol in the flow reactor. Because, as noted above, reversibly adsorbed $\mathrm{HNO}_{3}$ is not detected in the aerosol phase, the uptake coefficient obtained this way is the probability that an $\mathrm{HNO}_{3}$ molecule colliding with the dust surface is irreversibly reacting with a dust component. Therefore, initial loss from the gas phase could be stronger than the quasi-steady state uptake coefficient assumed in this approach. The rate equation for the depletion of radioactively labelled $\mathrm{HNO}_{3}$ from the gas phase in the cylindrical flow tube is given by

$$
-\frac{d C_{\mathrm{g}}}{d t}=\left(k_{\mathrm{w}}+k_{\mathrm{p}}\right) C_{\mathrm{g}}
$$

where $C_{\mathrm{g}}$ is the average concentration of $\mathrm{HNO}_{3}$ in gas phase. $k_{\mathrm{W}}$ is the constant which describes the pseudo first order loss of $\mathrm{H}^{13} \mathrm{NO}_{3}$ from the gas phase due to its adsorption to the walls of the reactor. $k_{\mathrm{p}}$ is the constant, which describes the heterogeneous reaction between gaseous nitric acid and aerosol particles. The presence of the wall-loss is rather specific for the radioactively labelled molecules used in this study and will be discussed in detail in the next section. Integration of the Eq. (2) with respect to time gives the concentration of $\mathrm{H}^{13} \mathrm{NO}_{3}$ molecules in the gas phase as a function of time:

$$
C_{\mathrm{g}}(t)=C_{\mathrm{g}}^{t=0} \exp \left\{-\left(k_{\mathrm{w}}+k_{\mathrm{p}}\right) t\right\}
$$




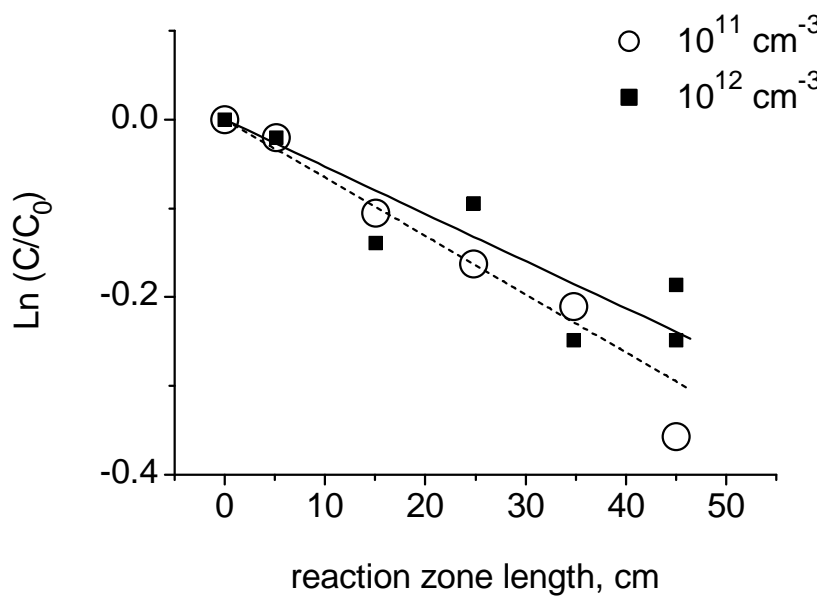

Fig. 4. Concentration of $\mathrm{H}^{13} \mathrm{NO}_{3}$ leaving the flow reactor in absence of aerosol at different injector positions, normalized by the initial concentration. Circles and squares represent the data points measured at $10^{11} \mathrm{~cm}^{-3}$ and $10^{12} \mathrm{~cm}^{-3}$, respectively, of $\mathrm{HNO}_{3}$ in flow tube and $33 \% \mathrm{RH}$. Lines are fits to the data according to the model explained in the text.

where $C_{\mathrm{g}}^{t=0}$ is the initial concentration at time zero. $k_{\mathrm{W}}$ can be obtained from the measurement of the concentration of $\mathrm{H}^{13} \mathrm{NO}_{3}(\mathrm{~g})$ as a function of time in absence of aerosol $\left(k_{\mathrm{p}}=0\right)$. The loss rate of $\mathrm{H}^{13} \mathrm{NO}_{3}(\mathrm{~g})$ in presence of the aerosol then allows determining $k_{\mathrm{p}}$.

The kinetics of appearance of $\mathrm{H}^{13} \mathrm{NO}_{3}$ in the particulate phase is given by:

$C_{\mathrm{p}}(t)=C_{\mathrm{g}}^{t=0} \frac{1-e^{-\left(k_{\mathrm{w}}+k_{\mathrm{p}}\right) t}}{1+\frac{k_{\mathrm{w}}}{k_{\mathrm{p}}}}$

where $C_{\mathrm{p}}(t)$ is the concentration of $\mathrm{H}^{13} \mathrm{NO}_{3}$ in the particulate phase.

In practice, we used Eq. (4) and not Eq. (3) to calculate the constant $k_{\mathrm{p}}$, because the experimental measurement of $C_{\mathrm{p}}$ is more accurate than that of $C_{\mathrm{g}}$. The heterogeneous constant $k_{\mathrm{p}}$ is related to the effective uptake coefficient $\gamma_{\text {eff }}$ according to following equation:

$k_{\mathrm{p}}=\frac{\gamma_{\mathrm{eff}} S_{\mathrm{p}} \omega}{4}$

where $S_{\mathrm{p}}$ is the aerosol surface to volume ratio, $\omega$ is the mean thermal velocity of $\mathrm{HNO}_{3}$ given by $\omega=(8 R T /(\pi M))^{1 / 2}, R$ is the gas constant, $T$ is the absolute temperature and $M$ is the molar weight of $\mathrm{HNO}_{3}$.

The value of $S_{\mathrm{p}}$ was obtained from the corrected SMPS measurements as described in the experimental section and the values of $k_{\mathrm{p}}$ and $\omega$ could be calculated using the equations listed above.

The value of the effective uptake coefficient, calculated in this way, depends slightly on the aerosol particle size, because gas phase diffusion affects the rate of transfer to larger particles more strongly than that to smaller particles. The diffusion correction was made using Eqs. (6) and (7) (Pöschl et al., 2005).

$$
\begin{aligned}
& \frac{1}{\gamma}=\frac{1}{\gamma_{\mathrm{eff}}}-\frac{0.75+0.28 K n}{K n(1+K n)} \\
& K n=\frac{6 D}{\omega d_{\mathrm{p}}}
\end{aligned}
$$

where $D$ is the diffusion coefficient of $\mathrm{HNO}_{3}, d_{\mathrm{p}}$ is aerosol particle diameter and $K n$ is the Knudsen number. Note that for the experiments reported in this study, the correction was always below $5 \%$ as discussed below.

\subsection{Retention of $\mathrm{H}^{13} \mathrm{NO}_{3}$ on the flow reactor wall}

The observations show that there is a steady state drop of the gas phase concentration of $\mathrm{H}^{13} \mathrm{NO}_{3}$ during passage through the flow reactor even without aerosol. As already pointed out by Guimbaud et al. (2002), this is not due to an irreversible chemical loss of $\mathrm{HNO}_{3}$ on the wall, but rather due to retention driven by adsorption and desorption. When considering the non-labelled $\mathrm{HNO}_{3}$ molecules, this effect leads to the well-known slow response time of this sticky gas measured at the reactor outlet when switching it on and off. At low concentrations, the observed response time is directly related to the average residence time of individual molecules in the flow tube. If this residence time is comparable to the half-life of the radioactive ${ }^{13} \mathrm{~N}$-tracer, $10 \mathrm{~min}$, a drop in the $\mathrm{H}^{13} \mathrm{NO}_{3}$ concentration along the flow tube can be observed, while the concentration of the non-labelled $\mathrm{HNO}_{3}$ concentration remains constant, if equilibrium with the wall is established. The level of non-labelled $\mathrm{HNO}_{3}$ and its response time in PFA tubes had been checked in separate test experiments related to this work but also to our earlier experiments (Guimbaud et al., 2002).

The details of lateral diffusion, adsorption, desorption, and radioactive decay are lumped into the pseudo-first order decay constant $k_{\mathrm{w}}$. Therefore, Eq. (3) with $k_{\mathrm{p}}=0$, was used to fit the experimentally observed $\mathrm{H}^{13} \mathrm{NO}_{3}(\mathrm{~g}$ ) concentration drop in absence of aerosol as shown in Fig. 4 for two examples. Typical residence times of $\mathrm{HNO}_{3}$ derived from these loss curves are about $4 \mathrm{~min}$, which seems comparable to the response on a similar material reported by Neuman et al. (1999). $k_{\mathrm{w}}$ obtained from these fits significantly decreased with increasing $\mathrm{HNO}_{3}$ concentration, possibly because saturation coverage of $\mathrm{HNO}_{3}$ on the PFA Teflon surface was reached above $10^{12}$ molecules $\mathrm{cm}^{-3} \cdot k_{\mathrm{w}}$ was also observed to increase with increasing relative humidity. This might be related to higher surface coverage by $\mathrm{H}_{2} \mathrm{O}$ molecules at higher relative humidity.

Apart from these effects, $k_{\mathrm{w}}$ also varied to some degree from tube to tube. Therefore, each time some parameter of the experimental system was changed or a new PFA flow tube 


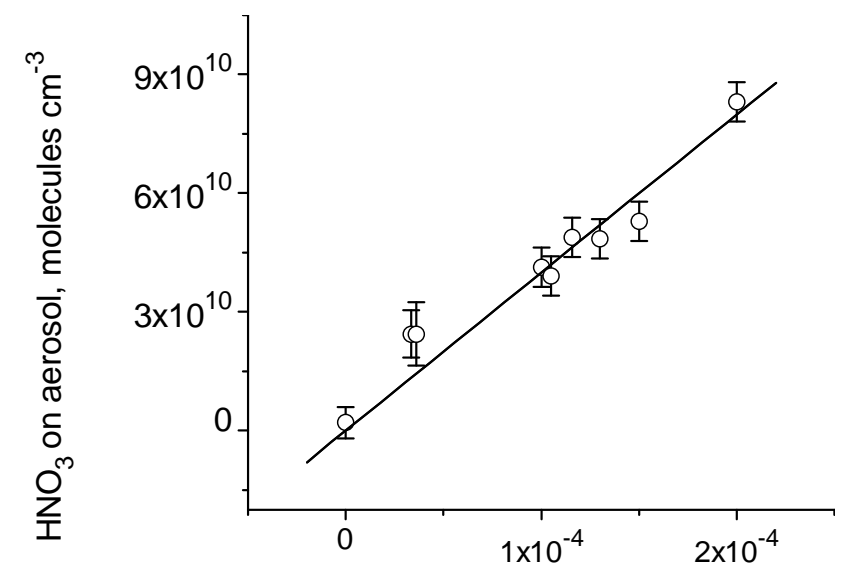

aerosol surface area, $\mathrm{cm}^{2} \mathrm{~cm}^{-3}$

Fig. 5. $\mathrm{HNO}_{3}$ reacted with ATD particles as a function of specific aerosol surface area. The nitric acid gas phase concentration in the flow tube was $10^{12} \mathrm{~cm}^{-3}$ and $R H 33 \%$.

was installed, a new measurement of $k_{\mathrm{w}}$ was performed. Explicitly, a measurement as shown in Fig. 4 was performed before each first aerosol admission into a new PFA tube. At the end of a series of measurements at different injector positions, the wall loss was rechecked with the injector fully pulled out, which was always consistent with the initial measurement. As mentioned in the experimental section, the strict flow tube replacement schedule ensured that the uptake measurement was not affected by particles residing on the flow tube wall.

\subsection{Effect of aerosol surface area and "diffusion resistance" on uptake}

The dependence of the amount of $\mathrm{H}^{13} \mathrm{NO}_{3}$ reacted on the aerosol of the aerosol surface area was investigated at an $\mathrm{HNO}_{3}$ concentration in the gas phase of $10^{12} \mathrm{~cm}^{-3}, R H$ of $33 \%$ and reaction time of $1.9 \mathrm{~s}$. The aerosol surface area was varied by changing the dust generator output, which results in a change of the particle number concentration but not particle size.

Figure 5 shows the number of $\mathrm{HNO}_{3}$ molecules reacted per $\mathrm{cm}^{3}$ as a function of the particle surface area per $\mathrm{cm}^{3}$. The error bars represent the $1 \sigma$ deviation of data about the mean. The amount of nitric acid reacted on the surface should be a linear function of the particle surface area, as long as $\left(k_{\mathrm{w}}+k_{\mathrm{p}}\right) t<1$, so that $C_{\mathrm{p}}(t) \approx C_{\mathrm{g}}^{t=0} k_{\mathrm{p}} t$, and for fixed reaction time $t, C_{\mathrm{p}} \propto S_{\mathrm{p}}$. This confirms that our experiment lies well within pseudo-first order kinetics and that the availability of $\mathrm{HNO}_{3}$ is not limiting the uptake.

To estimate the limitation of uptake by the diffusion of $\mathrm{HNO}_{3}$ in the gas phase we use the expressions (6) and (7). The $\mathrm{HNO}_{3}$ diffusion coefficient $D$ has been taken as
Table 1. Flow reactor parameters and measurement conditions.

\begin{tabular}{ll}
\hline Parameter & Value \\
\hline Reaction time & $0.2-2 \mathrm{~s}$ \\
Concentration $\mathrm{H}^{13} \mathrm{NO}_{3}$ (labelled) & $\sim 10^{6} \mathrm{~cm}^{-3}$ \\
Concentration of $\mathrm{HNO}_{3}$ (not labelled) & $10^{11}-10^{12} \mathrm{~cm}^{-3}$ \\
Pressure & $\sim 1 \mathrm{~atm}$ \\
Relative humidity & $12-73 \%$ \\
\hline
\end{tabular}

Table 2. Conditions of the uptake experiments and the results of the fits to the data. ${ }^{*}$ The accuracy is calculated on the basis of the measurement done for $2 \mathrm{~s}$ reaction time (contact time for $k_{\mathrm{W}}$ ).

\begin{tabular}{lll}
\hline parameter & $\begin{array}{c}\mathrm{HNO}_{3} \text { concentration in the gas phase } \\
\text { in flow reactor, molecules cm } \\
(1 \pm 0.5) \times 10^{11}\end{array}$ & $(10 \pm 1) \times 10^{11}$ \\
\hline$R H, \%$ & $33 \pm 1$ & $33 \pm 1$ \\
$S_{\mathrm{p}} \times 10^{-5}, \mathrm{~cm}^{2} \mathrm{~cm}^{-3}$ & $9 \pm 2$ & $13 \pm 3$ \\
$k_{\mathrm{W}}, \mathrm{s}^{-1}$ & $0.15 \pm 0.02^{*}$ & $0.11 \pm 0.04^{*}$ \\
$k_{\mathrm{p}}, \mathrm{s}^{-1}$ & $0.063 \pm 0.009^{*}$ & $0.025 \pm 0.01^{*}$ \\
$\gamma_{\mathrm{eff}}$ & $0.11 \pm 0.03$ & $0.03 \pm 0.01$ \\
$\gamma$ & $0.11 \pm 0.03$ & $0.03 \pm 0.01$ \\
\hline
\end{tabular}

$0.118 \mathrm{~cm}^{2} \mathrm{~s}^{-1}$ (Durham and Stockburger, 1986), which had been measured in air at atmospheric pressure, $298 \mathrm{~K}$ and 595\% relative humidity. The "diffusion limitation" effect is stronger for higher values of the uptake coefficient. Based on Eqs. (6) and (7), the maximum correction $\gamma / \gamma_{\text {eff }}$ is 1.5 at 1 micrometer particle diameter for $\gamma_{\text {eff }}=0.1$. When integrated over the full aerosol spectrum of ATD, the correction is about $5 \%$ or less for smaller values of $\gamma$.

\subsection{Uptake coefficient on Arizona Test Dust aerosol}

The experimental data of the $\mathrm{H}^{13} \mathrm{NO}_{3}(\mathrm{~g})$ concentration drop and the corresponding gain of $\mathrm{H}^{13} \mathrm{NO}_{3}(\mathrm{p})$ in the aerosol phase shown in Fig. 6 was fitted using Eqs. (4) and (5), with $k_{\mathrm{p}}$ as independent variable. The constant $k_{\mathrm{p}}$ was varied using the least square method to achieve the best agreement between the data points of the concentration in the aerosol phase and model curve, calculated by Eq. (4), because, as noted above, the changes in the aerosol phase could be detected with better accuracy than those in the gas phase. The result is given in Fig. 5 and Table 2. The fit and the data agree quite well. One should notice that within accuracy of the experiment the drop of the $\mathrm{HNO}_{3}$ (g) concentration due to uptake to the aerosol corresponds to the growth of the $\mathrm{HNO}_{3}(\mathrm{p})$ signal. Most of the discrepancy between data and model has been assigned to the instability of aerosol generation. For instance, the deviation of the data points from the fit at $1.9 \mathrm{~s}$ 


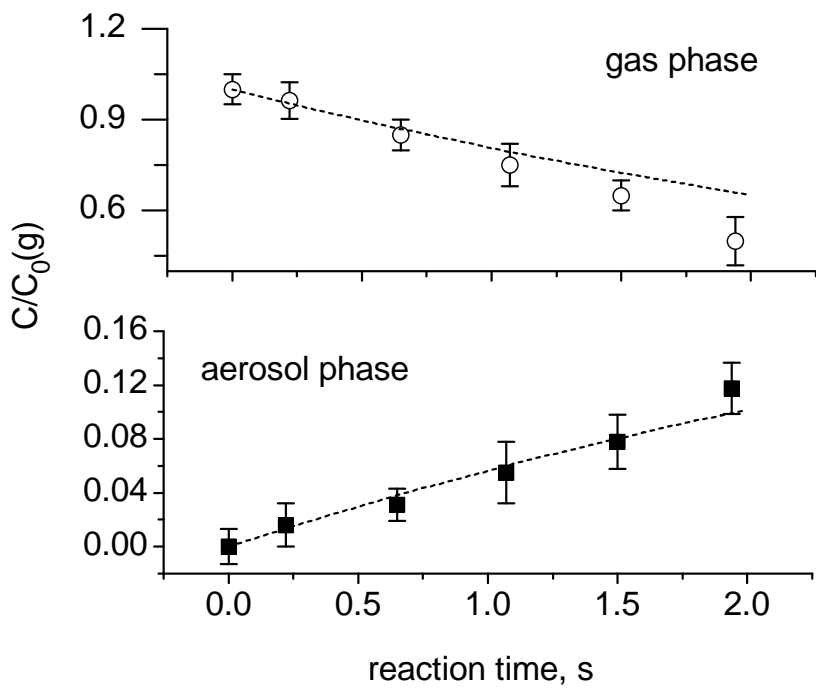

Fig. 6. Change of the $\mathrm{HNO}_{3}$ concentration in the gas (open circles) and particulate (solid squares) phases as a function of reaction time. Experimental data are represented as the concentrations normalized by the concentration in the gas phase at reaction zero time. The dashed lines are the model fits. The $\mathrm{HNO}_{3}$ gas phase concentration in the flow tube was $10^{11} \mathrm{~cm}^{-3}$ and $R H 33 \%$. The error bars represent the $1 \sigma$ deviation of data about the mean.

reaction time in the example shown in Fig. 6 is due to an increase of the aerosol surface area recorded by the SMPS system at that time and as a result a higher uptake to the aerosol phase and stronger depletion of the $\mathrm{HNO}_{3}$ concentration in the gas phase.

The uptake coefficient is found to be a function of $\mathrm{HNO}_{3}$ concentration in the gas phase (Table 2). At higher concentration of nitric acid in the flow tube the uptake coefficient drops by more than a factor of three. Previous work on this and similar heterogeneous reaction systems indicate that the $\mathrm{HNO}_{3}+$ mineral dust reaction could be considered as a two stage process: adsorption of $\mathrm{HNO}_{3}$ on the dust surface followed by a reaction of the adsorbed $\mathrm{HNO}_{3}$ with a basic surface site (surface $\mathrm{OH}$-group on aluminosilicate or similar minerals or bulk $\mathrm{CaCO}_{3}$ ). Therefore, the decrease of the uptake coefficient, which is an average over the two seconds reaction time, could be either due to the depletion of the reaction sites or due to saturation of the adsorbed precursor (Ammann et al., 2003). The available data points at $\mathrm{HNO}_{3}(\mathrm{~g})$ concentration $10^{12} \mathrm{~cm}^{-3}$ still fit the model (which assumes an average uptake coefficient over the time scale of the experiment) reasonably well, so that depletion of the reactants during the early periods of the reaction time is likely not the reason for the concentration dependence. While the amount of $\mathrm{HNO}_{3}$ found on the particle surface after two seconds of about $2 \times 10^{14}$ molecules $\mathrm{cm}^{-2}$ could be considered close to a monolayer surface coverage, the degree with which components contained in the bulk of the particles can react and thus extend the capacity of the particles to react is not

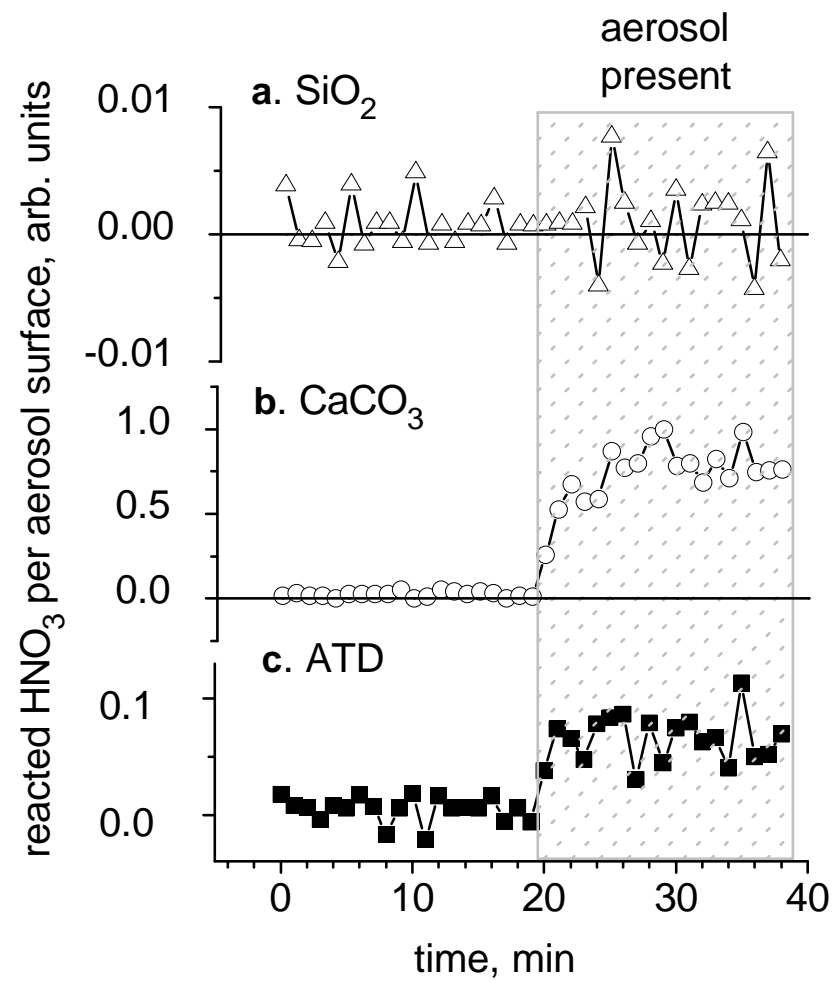

Fig. 7. Online record of uptake experiments between gaseous $\mathrm{HNO}_{3}$ and aerosol particles of different materials. Panels (a), (b), (c) represent the reactions with the aerosol composed of silica, calcium carbonate and Arizona Test Dust, respectively. The time period 0-20 min corresponds to the background readings of the detector. The grey bar (20-40 min) corresponds to the time when aerosol was present in the flow reactor. The $\mathrm{HNO}_{3}$ gas phase concentration in the flow tube was $10^{12} \mathrm{~cm}^{-3}$ and $R H 33 \%$.

known. Therefore, this apparent non-first order behavior of the rate of product appearance indicates that the simple approach adopted here is not sufficient to retrieve a reliable parameterization of the kinetics. A more extended kinetic data set associated with proper kinetic modeling is necessary to extract the parameters describing the elementary processes of the uptake process. This will be part of a follow-up study of this, while here we concentrate on the humidity dependence.

\subsection{Uptake coefficient on $\mathrm{SiO}_{2}$ and $\mathrm{CaCO}_{3}$ aerosols}

In an attempt to understand the mechanism of the heterogeneous reaction between $\mathrm{HNO}_{3}$ and the ATD and for the purpose of comparison with other studies, we also made experiments of uptake of $\mathrm{HNO}_{3}$ to silica and calcite aerosol particles.

Figure 7 shows the uptake of the gaseous nitric acid to silica and $\mathrm{CaCO}_{3}$ aerosol particles. To simplify the discussion of this comparison, we show the raw data in the same way as discussed in Sect. 3.1 above. The experiment starts with 
recording the background detector signal, as shown in Fig. 3. After $20 \mathrm{~min}$, the aerosol is introduced into the flowtube, adjusted to a reaction time of $1.9 \mathrm{~s}$. One may see that the detector signal level does not change with the introduction of $\mathrm{SiO}_{2}$ particles at a statistically significant level. This means that silica aerosol seems rather inert with respect to reaction with $\mathrm{HNO}_{3}$. Assuming the detection limit at $3 \sigma$ of the background noise level of the signal of the $\gamma$-detector at the aerosol filter and taking into account the measured $\mathrm{SiO}_{2}$ aerosol surface area of $10^{11} \mathrm{~cm}^{2} \cdot \mathrm{cm}^{-3}$, an upper limit to the uptake coefficient of $5 \times 10^{-4}$ is obtained. This result is in agreement with the Knudsen cell study of Underwood et al. (2001) who reported the uptake of $\mathrm{HNO}_{3}$ to a $\mathrm{SiO}_{2}$ surface "too low to be measured". Goodman et al. (2001) studied the heterogeneous reaction of silica powder with gaseous nitric acid using transmission FT-IR spectroscopy and classified the $\mathrm{SiO}_{2}$ as a non-reactive neutral oxide with respect to this reaction. The authors also concluded that the adsorption of nitric acid on silica surface is reversible at $296 \mathrm{~K}$. This is also in agreement with the data of the present study because $\mathrm{HNO}_{3}$ reversibly adsorbed to the $\mathrm{SiO}_{2}$ particles in the flowtube is desorbed in the denuder and not detected in the aerosol phase. This reversible nature of $\mathrm{HNO}_{3}$ adsorption on silica surfaces was also reported by Dubowski et al. (2004) who found no significant amounts of covalently bonded nitrate on glass and quartz surface after exposure to $\mathrm{HNO}_{3}$.

In contrast, $\mathrm{CaCO}_{3}$ particles are more reactive with respect to nitric acid than ATD, as also shown in Fig. 7. The uptake to $\mathrm{CaCO}_{3}$ is almost 4 times higher than to ATD. This is not surprising, since the reactivity of $\mathrm{CaCO}_{3}$ with $\mathrm{HNO}_{3}$ is well known, while ATD contains only little $\mathrm{CaCO}_{3}$ but much more of the less reactive silica and alumino-silicates. This is in agreement with the studies of Krueger et al. (2003, 2004), which showed the formation of $\mathrm{Ca}\left(\mathrm{NO}_{3}\right)$ in single $\mathrm{CaCO}_{3}$ and authentic dust particles as a reaction product at conditions close to the experimental conditions of this study ( $R H$ $38 \%, \mathrm{HNO}_{3}$ concentration $4.6 \times 10^{11}$ molecules $\mathrm{cm}^{-3}$ ).

To some extent the nature of the mineral surface under the humid conditions of the present study could be rationalized from the way how the major mineral constituents are expected to dissolve in near neutral or acidic aqueous solution (Desboeufs et al., 2003; Schott and Oelkers, 1995) :

$\mathrm{SiO}_{2}$ (quartz) $+2 \mathrm{H}_{2} \mathrm{O} \Leftrightarrow \mathrm{H}_{4} \mathrm{SiO}_{4}$

Albite $+\mathrm{H}^{+} \Leftrightarrow \mathrm{H}_{1 / 3} \mathrm{Al}_{1 / 3} \mathrm{SiO}_{8 / 3}$ (hydrogeneted albite)

$+\mathrm{Na}^{+}\left(\mathrm{K}^{+}\right)$

$\mathrm{H}_{1 / 3} \mathrm{Al}_{1 / 3} \mathrm{SiO}_{8 / 3}+\mathrm{H}^{+}+(\mathrm{n}-2 / 3) \mathrm{H}_{2} \mathrm{O}$

$\Leftrightarrow\left(\mathrm{SiO}_{2} \cdot \mathrm{nH}_{2} \mathrm{O}\right)+1 / 3 \mathrm{Al}^{3+}$

$\mathrm{CaCO}_{3}$ (calcite) $+\mathrm{H}^{+} \Leftrightarrow \mathrm{HCO}_{3}^{-}+\mathrm{Ca}^{2+}$

This list of reactions is not complete and one should also consider the dissolution of minor components of the ATD: microcline, illite, etc. Most of these minerals dissolve similar

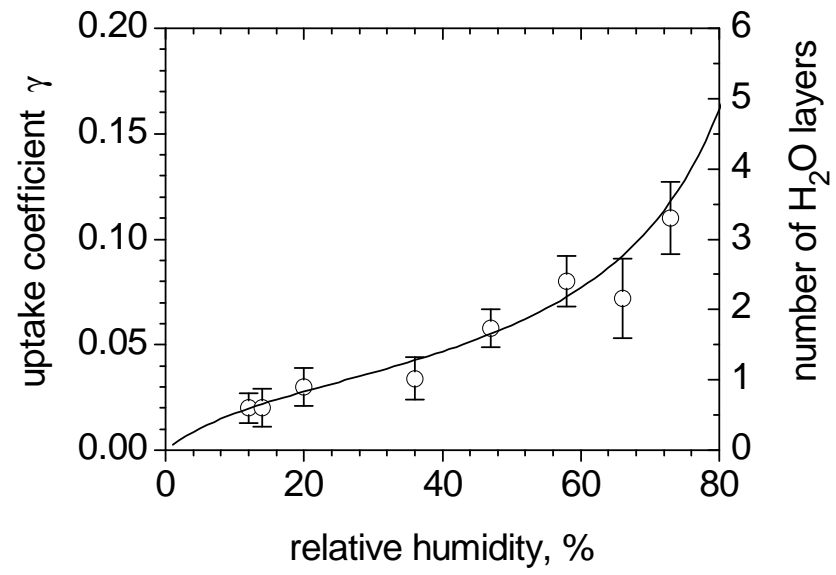

Fig. 8. Uptake coefficient of nitric acid to ATD mineral dust aerosol as a function of relative humidity. Open circles represent the experimental values of the uptake coefficient (reaction time $1.9 \mathrm{~s}$, the concentration of nitric acid in the flow tube was $10^{12} \mathrm{~cm}^{-3}$ ). The solid line represents a BET isotherm (Eq. 12, $c=8$ ) for water adsorption, scaled to match the uptake data.

to albite and some could additionally release $\mathrm{Mg}^{2+}$ cations. Exposure of ATD to $\mathrm{HNO}_{3}$ under humid conditions certainly helps promoting these hydrolysis processes by providing protons. Even though these hydrolysis processes might not be complete on the surface, especially at relatively low humidity, partial solvation might be enough for providing a reactive site to $\mathrm{HNO}_{3}$.

\subsection{Effect of humidity on uptake}

The hydrolysis Reactions (8) to (11), which might promote the surface (and eventually also bulk) reactivity of dust towards $\mathrm{HNO}_{3}$, are directly suggesting that a significant humidity dependence should exist. The effect of variation in relative humidity on the uptake coefficient was investigated using a fixed $\mathrm{HNO}_{3}$ concentration of $10^{12}$ molecules $\mathrm{cm}^{-3}$ and a fixed reaction time of $1.9 \mathrm{~s}$. Note that in this case, also the determination of $k_{\mathrm{w}}$ was based on the measurement of $\mathrm{HNO}_{3}$ in absence of aerosol at the positions 0 and $40 \mathrm{~cm}$ only. This leads to relatively small precision uncertainties of the data shown in Fig. 8. The systematic errors due to issues discussed further below and included in the errors shown in Table 2 are not included in Fig. 8. The data show that $\gamma$ increases steadily from $0.022 \pm 0.007$ at $12 \%$ $R H$ to $0.113 \pm 0.017$ at $73 \% R H$. A possible explanation to this is the increasing amount of $\mathrm{H}_{2} \mathrm{O}$ adsorbed on the surface of ATD particles, which may promote the hydrolysis processes. Some information on the amount of water associated with ATD aerosol can be obtained from the hygroscopic growth of ATD aerosol particles investigated in a previous study (Vlasenko et al., 2005). The main conclusion was that the ATD particles adsorb water under increasing $R H$ conditions, to some degree related to the presence of water soluble 
material. However, the small size changes did not allow retrieving a well resolved water adsorption isotherm. For bulk oxide materials it has been shown that several monolayers of water can be formed on the surfaces of $\mathrm{SiO}_{2}, \mathrm{Al}_{2} \mathrm{O}_{3}$ and $\mathrm{CaCO}_{3}$ with increasing relative humidity (Al-Abadleh and Grassian, 2003; Goodman et al., 2001, 2000). Similar behavior was shown for water adsorption on a borosilicate glass surface (Dubowski et al., 2004; Sumner et al., 2004). These authors have adapted the BET equation (Adamson, 1982) to describe water adsorption on the surface of solids. We used the same approach to calculate the isotherm for the adsorption of water by

$\Theta_{\mathrm{H}_{2} \mathrm{O}}=\frac{c R H}{(1-R H)(1-(1-c) R H)}$

One can see in Fig. 8 that this isotherm has a similar shape in the relevant humidity range as the experimental data of the uptake coefficient of $\mathrm{HNO}_{3}$ on ATD, even though this similarity is by no means a proof that the kinetics is directly related to this very general adsorption isotherm. This observation continues the suite of "BET isotherm like" humidity dependent heterogeneous reactions on solid surfaces: $\mathrm{HNO}_{3}(\mathrm{~g})+\mathrm{NaCl}(\mathrm{s})$ (Davies and Cox, 1998), $\mathrm{HNO}_{3}(\mathrm{~g})+\mathrm{CaCO}_{3}$ (s) (Goodman et al., 2000), $\mathrm{NO}_{2}+1,2,10$-anthracenetriol (s) (Arens et al., 2002) and $\mathrm{NO}_{2}+$ borosilicate glass (Finlayson-Pitts et al., 2003), in all of which hydrolysis of the substrate provides the reactive components. This contrasts other heterogeneous processes, such as oxidation reactions (Adams et al., 2005; Pöschl et al., 2001), in which water adsorption competes with the adsorbing gaseous reactant, so that humidity has an inhibiting or no effect on the overall process.

Furthermore, the increase of the uptake coefficient with humidity measured in this study is consistent with data from the ACE-Asia field campaign, that suggested that the mass accommodation coefficient of $\mathrm{HNO}_{3}$ on ambient dust might increase with increasing humidity (Maxwell-Meier et al., 2004). Recently Umann et al. (2005) have published the results from the field study of the heterogeneous interaction between Sahara dust particles and $\mathrm{HNO}_{3}$. Although, the authors reported no RH-dependence of the uptake coefficient, the absolute values of $\gamma_{\mathrm{HNO}_{3}}$, estimated from their field observations, are in agreement with the values of this study for the respective humidity range.

\subsection{Comparison to literature data}

Several aspects should be considered, when comparing the uptake data of the present study to those currently available in the literature as listed in Table 3. Our data suggest a significant humidity dependence of the uptake coefficient, at least for higher humidity, while the previously available kinetic studies were all performed under completely dry conditions. If we would extrapolate our data along the water adsorption isotherm to very low humidity $(0.1 \% R H)$ in Fig. 8, we ex- pect the uptake coefficient to get into the range of $10^{-3}$ for ATD, and a similar shift might be expected for the uptake on $\mathrm{CaCO}_{3}$, if we would assume a similar dependence on humidity. On the other hand, in absence of data in this humidity range, one could also argue that the uptake coefficient does not decrease as suggested by the adsorption isotherm. Hanisch et al. (2001) report an about a factor of 2 change in the uptake coefficient on $\mathrm{CaCO}_{3}$ measured under dry conditions, when water remaining after evacuation was further removed by baking the dust powder. This indicates that also more strongly bound water, which is not described by the BET isotherm shown in Fig. 8, is able to promote the reaction with $\mathrm{HNO}_{3}$, or might be even decisive for it.

A second aspect relates to the issue of surface area to normalize the uptake according to Eq. (2). The significant disagreement between the values reported by Goodman et al. (2000) and by Johnson et al. (2005) on the one hand and those reported by Fenter et al. (1995) and Hanisch et al. (2001) on the other are due to different ways of taking into account internal surface areas of the powders used. Goodman et al. (2000) measured the specific area of $\mathrm{CaCO}_{3}$ powder with a BET method and applied the Keyser-Moore-Leu model (Keyser et al., 1991) to account for the contribution by the internal surface area, while Fenter and Hanisch referred to the geometric sample surface area to calculate the collisional flux in the molecular flow regime to the external powder surface. In our study with suspended aerosol particles, we estimate the reactive surface area from the measurement of the mobility diameter (measured by SMPS) and assuming that the particles are spherical, even though it has been shown (Vlasenko et al., 2005) that the ATD particles used in this study are not perfectly spherical and could be to some degree agglomerates, especially for particle sizes larger than $200 \mathrm{~nm}$. Experimentally, the relation between the surface of aerosol agglomerates available for reaction and the surface measured by SMPS is only known for a perfectly sticking $(\gamma=1)$ species, namely ${ }^{211} \mathrm{~Pb}$ atoms. Rogak et al. (1991) experimentally proved that the mobility diameter measured by SMPS is equal to the "mass transfer" diameter not only for spherical particles but also for complex agglomerates, namely soot. Other existing theoretical approaches to account for the additional internal surface of aerosol agglomerates rely strongly on empirical parameters (Naumann, 2003; Xiong et al., 1992). In the absence of a more accurate way to evaluate the true dust surface area (available for reaction with $\mathrm{HNO}_{3}$ ) we used the surface area obtained from the SMPS measurements to calculate the uptake coefficient. Bearing in mind that only part of all the particles are slightly agglomerated (particles larger than $200 \mathrm{~nm}$ ) we guess a not more than $20 \%$ systematic underestimation of the dust surface area given by the SMPS. This is included in the overall error associated with the uptake coefficients shown in Table 2. We would also like to point out that all atmospheric field measurements either use a total dust mass or surface area assuming spherical geometry, i.e. the measurements made in this 
Table 3. Uptake coefficient measured for aerosol particles of different composition. KC, DRIFTS and FT are abbreviations of Knudsen Cell, Diffuse reflectance infrared spectroscopy and Flow Tube reactors, respectively. Only average values of uptake coefficients and orders of magnitude $\mathrm{HNO}_{3}$ concentrations are given for conciseness. ${ }^{*}$ Values are given for nonheated and heated sample respectively. ${ }^{* *}$ Uptake measured at $R H 33 \% .{ }^{1}$ Uptake coefficient is calculated using geometric surface area of dust sample. ${ }^{2}$ uptake coefficient is calculated using BET data and pore diffusion model.

\begin{tabular}{lcccccc}
\hline Study & Reactor & Sample & $\begin{array}{c}\mathrm{HNO}_{3} \\
\mathrm{Conc}, \mathrm{cm}^{-3}\end{array}$ & & Composition & \\
& & & & $\mathrm{SiO}_{2}$ & $\mathrm{CaCO}_{3}$ & ATD \\
\hline Fenter et al. (1995) & $\mathrm{KC}^{1}$ & powder & $10^{10}-10^{13}$ & & 0.15 & \\
Goodman et al. (2001) & DRIFTS & powder & $10^{14}-10^{15}$ & $10^{-9}$ & & \\
Goodman et al. (2000) & KC & powder & $10^{12}$ & & $2.5 \times 10^{-4}$ & \\
Underwood et al. (2000) & $\mathrm{KC}^{2}$ & powder & $10^{11}$ & & $1.4 \times 10^{-5}$ & \\
Johnson et al. (2005) & $\mathrm{KC}^{2}$ & powder & $10^{11}$ & & $2 \times 10^{-3}$ & \\
Hanisch et al. (2001) & $\mathrm{KC}^{1}$ & powder & $10^{11}-10^{12}$ & & $0.18,0.1^{*}$ & \\
& & & $10^{11}-10^{12}$ & & & 0.06 \\
Seisel et al. (2004) & DRIFTS & powder & $10^{11}-10^{12}$ & & & 0.016 \\
this work* & FT & aerosol & $10^{12}$ & $<5 \times 10^{-4}$ & 0.11 & 0.03 \\
& & & $10^{11}$ & & & 0.11 \\
\hline
\end{tabular}

paper (also assuming spherical geometry) are well suited to comparison to those that may prevail in the atmosphere.

3.9 Implications for the hygroscopic properties of ATD aerosol

One of the atmospherically relevant consequences of the heterogeneous interaction between $\mathrm{HNO}_{3}(\mathrm{~g})$ and mineral dust is the associated change of hygroscopic properties of the dust particles. Figure 9 shows the hygroscopic growth of ATD particles before and after reaction with gaseous nitric acid and water vapor. When dust particles are exposed to $\mathrm{HNO}_{3}$ $\left(3 \times 10^{13}\right.$ molecules $\left.\mathrm{cm}^{-3}\right)$ for $3 \mathrm{~min}$ at $30 \%$ relative humidity the hygroscopic properties do not change significantly (Fig. 9a). The exposure in this experiment corresponds to the integrated exposure of an atmospheric dust particle to 0.1$1 \mathrm{ppb}$ of $\mathrm{HNO}_{3}$ during a typical life-time of 1-10 days, even though we are aware that in view of the concentration dependence observed this might be an over-simplification. The ATD hygroscopicity is significantly changed after weathering the particles at the same concentration of $\mathrm{HNO}_{3}$ and $85 \% R H$. Figure $9 \mathrm{~b}$ shows that after the exposure the particle diameter is increased by $7 \%$ while increasing the humidity from $10 \%$ to $78 \%$. This finding is consistent with the kinetic data that show a strong effect of humidity on the speed and extent of processing of the dust particles by $\mathrm{HNO}_{3}$ (Fig. 8).

Even though the formation of a liquid phase is thermodynamically not favored (for the pure $\mathrm{HNO}_{3}-\mathrm{H}_{2} \mathrm{O}$ system) under our conditions, we nevertheless assume that the concomitant exposure to nitric acid and high humidity of $85 \%$ over longer time scales promotes the significant dissolution of the particle surface material through Reactions (8) to (11) (Desboeufs et al., 2003; Schott and Oelkers, 1995). Desboeufs et

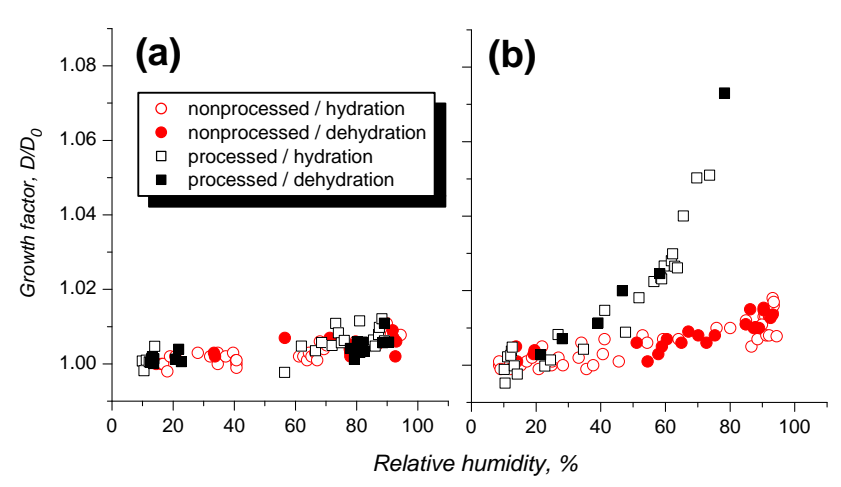

Fig. 9. Hygroscopic growth of ATD particles before (circles) and after (squares) reaction with gaseous nitric acid $\left(3 \times 10^{13}\right.$ molecules $\mathrm{cm}^{-2}$ ) and water vapour. (a): circles represent ATD particles with $D_{0}=100 \mathrm{~nm}$ before reaction, squares represent particles of the same size after reaction with $\mathrm{HNO}_{3}$ at $30 \% R H$. (b): circles represent ATD particles before reaction, squares represent ATD particles after reaction with $\mathrm{HNO}_{3}$ at $85 \% R H . D_{0}$ is the mobility size of monodisperse particles at lowest $R H$ at $20^{\circ} \mathrm{C}$. Open and solid symbols correspond to hydration and dehydration curves, respectively.

al. (1999) studied the dissolution rates of different elements from Sahara dust at different $\mathrm{pH}$ and reported the increasing solubility sequence $\mathrm{Si}<\mathrm{Mg}<\mathrm{Ca}<\mathrm{K}<\mathrm{Na}$. From these data we concluded that the uptake of $\mathrm{HNO}_{3}$ from the gas phase to mineral dust particles at $85 \% R H$ increases the acidity of the adsorbed water layers and strongly promotes the dissolution of major minerals. The weathering of silica is believed to be small on a time scale of our experiment ( $3 \mathrm{~min}$ ). In our experiments, after the processing the aerosol was dried, and possibly separate phases of $\mathrm{Ca} / \mathrm{Mg} / \mathrm{Na}$ nitrates are formed on 
the particles. Laskin et al. (2005b) interpreted the increase the $\mathrm{O}, \mathrm{N}$ atomic content of the Ca-rich mineral dust particles after $\mathrm{HNO}_{3}(\mathrm{~g})$ exposure as formation of calcium nitrate. We use the assumption (that the reaction product is $\mathrm{Ca}\left(\mathrm{NO}_{3}\right)_{2}$ ) to calculate the amount of product built up after processing of ATD with gaseous nitric acid. Using the approach of Saathoff et al. (2003) and assuming spherical shape of particles and independent additive hygroscopic behaviour of the different components one may calculate the volume fraction of $\mathrm{Ca}\left(\mathrm{NO}_{3}\right)_{2}$ coating on the processed particles according to the following equation:

$\epsilon=\frac{G F_{\text {proc }}^{3}-G F_{\text {nonproc }}^{3}}{G F_{\mathrm{Ca}\left(\mathrm{NO}_{3}\right)_{2}}^{3}-G F_{\text {nonproc }}^{3}}$

where $G F_{\text {proc }}$ and $G F_{\text {nonproc }}$ are hygroscopic growth factors of the processed and nonprocessed ATD particles, respectively. $G F_{\mathrm{Ca}\left(\mathrm{NO}_{3}\right)_{2}}$ is a hygroscopic growth factor of pure calcium nitrate, which is quite similar to the other soluble nitrates in dust (sodium nitrate and magnesium nitrate).

Using the measured values of the hygroscopic growth factors (Fig. 9b) for the ATD and the literature value for the calcium nitrate hygroscopic growth (Tang and Fung, 1997) as a proxy for the behaviour of the soluble nitrates, we calculate a $8 \%$ volume fraction of $\mathrm{Ca}\left(\mathrm{NO}_{3}\right)_{2}$ in the processed particles. Expressed as an external coating, this corresponds to an about $1 \mathrm{~nm}$ thick layer. This rough estimate shows that several monolayers of hygroscopic reaction products could be formed on the surface of the ATD particles as a result of processing with gaseous nitric acid. This is consistent with findings by Dubowski et al. (2004) reporting surface segregation of trace metal oxides and their nitrates formed from the reaction of $\mathrm{HNO}_{3}$ with borosilicate glass. Note that extrapolation of our processing experiment to atmospheric conditions is only valid under the assumption that the degree of processing is a function of the integrated exposure only and not a function of $\mathrm{HNO}_{3}$ concentration during the exposure.

\section{Atmospheric implications}

The major atmospheric implication of this study is the experimentally determined humidity dependence of the heterogeneous uptake on the dust aerosol. It has been shown that increasing the relative humidity promotes the uptake of nitric acid. However, recent modeling studies (Bauer et al., 2004; Bian and Zender, 2003; Tang et al., 2004) consider the heterogeneous reactivity of the dust independent of relative humidity. While the order of magnitude of the uptake coefficient used by Bauer et al. (2004) based on the data of Hanisch and Crowley (2001) obtained under very dry conditions $(R H<1 \%)$ is similar to what we report here, we strongly suggest that a humidity dependent uptake coefficient scaling along a water isotherm as shown in Fig. 8 could be used in modeling studies. Implementing this dependence into global dust models will certainly reduce their uncertainty.
Another atmospherically relevant outcome of the present study is the experimental evidence that extensive processing of mineral dust by $\mathrm{HNO}_{3}(\mathrm{~g})$ and possibly other acidic gases results in significant hygroscopic growth. Recently, several studies have been performed, which investigated the chemical composition of mineral dust particles collected in different regions. These studies reported evidence of morphology and composition modifications due to reaction with $\mathrm{HNO}_{3}$ in the atmosphere (Matsuki et al., 2005; Laskin et al., 2005a; Hwang et al., 2005). The enhanced water uptake by dust particles increases their interaction with solar radiation. To illustrate this effect we estimate an increase of the dust single scattering albedo (SSA). SSA is the commonly used measure of the relative contribution of absorbing aerosol to extinction and is a key variable in assessing the climatic effect of the aerosol (Seinfeld et al., 2004). Assuming that the processing does not change the refractive index $(n=1.52, k=0.00133)$ of the dust shown on Fig. 9b and only increases the particle size we estimate 3\% increase of the SSA for the aged dust at $550 \mathrm{~nm}$ wavelength of incident light. This calculation is very crude but indicates the potential of the dust aging process to affect the radiation balance of the planet.

Acknowledgements. We would like to thank M. Birrer for his excellent technical support. We also greatly acknowledge the staff of the PSI accelerator facility for their efforts to provide a stable proton beam. We appreciate financial support by the Swiss National Science Foundation (grant no. 200020-100275).

Edited by: Y. Rudich

\section{References}

Adams, J. W., Rodriguez, D., and Cox, R. A.: The uptake of $\mathrm{SO}_{2}$ on Saharan dust: a flow tube study, Atmos. Chem. Phys., 5, 2679-2689, 2005, mboxhttp://www.atmoschem-phys.net/5/2679/2005/.

Adamson, A. W.: Physical Chemistry of Surfaces, John Wiley \& Sons, New York, 1982.

Al-Abadleh, H. A. and Grassian, V. H.: FT-IR study of water adsorption on aluminum oxide surfaces, Langmuir, 19, 341-347, 2003.

Ammann, M.: Using ${ }^{13} \mathrm{~N}$ as tracer in heterogeneous atmospheric chemistry experiments, Radiochim. Acta, 89, 831-838, 2001.

Ammann, M., Pöschl, U., and Rudich, Y.: Effects of reversible adsorption and Langmuir-Hinshelwood surface reactions on gas uptake by atmospheric particles, Phys. Chem. Chem. Phys., 5, 351-356, 2003.

Archuleta, C. M., DeMott, P. J., and Kreidenweis, S. M.: Ice nucleation by surrogates for atmospheric mineral dust and mineral dust/sulfate particles at cirrus temperatures, Atmos. Chem. Phys., 5, 2617-2634, 2005, mboxhttp://www.atmoschem-phys.net/5/2617/2005/.

Arens, F., Gutzwiller, L., Gäggeler, H. W., and Ammann, M.: The reaction of $\mathrm{NO}_{2}$ with solid anthrarobin (1,2,10-trihydroxyanthracene), Phys. Chem. Chem. Phys., 4, 3684-3690, 2002. 
Aschmutat, U., Hessling, M., Holland, F., and Hofzumahaus, A.: A tunable source of hydroxyl $(\mathrm{OH})$ and hydroperoxy $\left(\mathrm{HO}_{2}\right)$ radicals: in the range between $10^{6}$ and $10^{9} \mathrm{~cm}^{-3}$, in: Physicochemical behaviour of atmospheric pollutants, edited by: Angeletti, G. and Restelli, G., European Commission, Luxembourg, 812-816, 1994.

Bauer, S. E., Balkanski, Y., Schulz, M., Hauglustaine, D. A., and Dentener, F.: Global modeling of heterogeneous chemistry on mineral aerosol surfaces: Influence on tropospheric ozone chemistry and comparison to observations, J. Geophys. Res.-Atmos., 109, D02304, doi:10.1029/2003JD003868, 2004.

Bian, H. S. and Zender, C. S.: Mineral dust and global tropospheric chemistry: Relative roles of photolysis and heterogeneous uptake, J. Geophys. Res.-Atmos., 108, 4672, doi:10.1029/2002JD003143, 2003.

Davies, J. A. and Cox, R. A.: Kinetics of the heterogeneous reaction of $\mathrm{HNO}_{3}$ with $\mathrm{NaCl}$ : Effect of water vapor, J. Phys. Chem. A, 102, 7631-7642, 1998.

DeMott, P. J., Sassen, K., Poellot, M. R., Baumgardner, D., Rogers, D. C., Brooks, S. D., Prenni, A. J., and Kreidenweis, S. M.: African dust aerosols as atmospheric ice nuclei, Geophys. Res. Lett., 30, 1732, doi:10.1029/2003GL017410, 2003.

Dentener, F. J., Carmichael, G. R., Zhang, Y., Lelieveld, J., and Crutzen, P. J.: Role of mineral aerosol as a reactive surface in the global troposphere, J. Geophys. Res.-Atmos., 101, 22 869$22889,1996$.

Desboeufs, K. V., Losno, R., and Colin, J. L.: Relationship between droplet $\mathrm{pH}$ and aerosol dissolution kinetics: Effect of incorporated aerosol particles on droplet $\mathrm{pH}$ during cloud processing, J. Atmos. Chem., 46, 159-172, 2003.

Desboeufs, K. V., Losno, R., Vimeux, F., and Cholbi, S.: The pHdependent dissolution of wind-transported Saharan dust, J. Geophys. Res.-Atmos., 104, 21 287-21 299, 1999.

Dubowski, Y., Sumner, A. L., Menke, E. J., Gaspar, D. J., Newberg, J. T., Hoffman, R. C., Penner, R. M., Hemminger, J. C., and Finlayson-Pitts, B. J.: Interactions of gaseous nitric acid with surfaces of environmental interest, Phys. Chem. Chem. Phys., 6, 3879-3888, 2004.

Durham, J. L. and Stockburger, L.: Nitric-Acid Air DiffusionCoefficient - Experimental-Determination, Atmos. Environ., 20, 559-563, 1986.

Fenter, F. F., Caloz, F., and Rossi, M. J.: Experimental-Evidence for the Efficient Dry Deposition of Nitric-Acid on Calcite, Atmos. Environ., 29, 3365-3372, 1995.

Finlayson-Pitts, B. J., Wingen, L. M., Sumner, A. L., Syomin, D., and Ramazan, K. A.: The heterogeneous hydrolysis of $\mathrm{NO}_{2}$ in laboratory systems and in outdoor and indoor atmospheres: An integrated mechanism, Phys. Chem. Chem. Phys., 5, 223-242, 2003.

Frinak, E. K., Wermeille, S. J., Mashburn, C. D., Tolbert, M. A., and Pursell, C. J.: Heterogeneous reaction of gaseous nitric acid on gamma-phase iron(III) oxide, J. Phys. Chem. A, 108, 15601566, 2004.

Goodman, A. L., Bernard, E. T., and Grassian, V. H.: Spectroscopic study of nitric acid and water adsorption on oxide particles: Enhanced nitric acid uptake kinetics in the presence of adsorbed water, J. Phys. Chem. A, 105, 6443-6457, 2001.

Goodman, A. L., Underwood, G. M., and Grassian, V. H.: A laboratory study of the heterogeneous reaction of nitric acid on cal- cium carbonate particles, J. Geophys. Res.-Atmos., 105, $29053-$ $29064,2000$.

Guimbaud, C., Arens, F., Gutzwiller, L., Gäggeler, H. W., and Ammann, M.: Uptake of $\mathrm{HNO}_{3}$ to deliquescent sea-salt particles: a study using the short-lived radioactive isotope tracer N-13, Atmos. Chem. Phys., 2, 249-257, 2002, mboxhttp://www.atmoschem-phys.net/2/249/2002/.

Hanisch, F. and Crowley, J. N.: Heterogeneous reactivity of gaseous nitric acid on $\mathrm{Al}_{2} \mathrm{O}_{3}, \mathrm{CaCO}_{3}$, and atmospheric dust samples: $\mathrm{A}$ Knudsen cell study, J. Phys. Chem. A, 105, 3096-3106, 2001.

Johnson, E. R., Sciegienka, J., Carlos-Cuellar, S., and Grassian, V. H.: Heterogeneous uptake of gaseous nitric acid on dolomite $\left(\mathrm{CaMg}\left(\mathrm{CO}_{3}\right)(2)\right)$ and calcite $\left(\mathrm{CaCO}_{3}\right)$ particles: A Knudsen cell study using multiple, single, and fractional particle layers, J. Phys. Chem. A, 109, 6901-6911, 2005.

Joseph, D. W. and Spicer, C. W.: Chemiluminescence Method for Atmospheric Monitoring of Nitric-Acid and Nitrogen-Oxides, Anal. Chem., 50, 1400-1403, 1978.

Hwang, H. J. and Ro, C. U.: Single-particle characterization of four aerosol samples collected in ChunCheon, Korea, during Asian dust storm events in 2002, J. Geophys. Res.-Atmos., 110, D23201, doi:10.1029/2005JD006050, 2005.

Kalberer, M., Tabor, K., Ammann, M., Parrat, Y., Weingartner, E., Piguet, D., Rössler, E., Jost, D. T., Türler, A., Gäggeler, H. W., and Baltensperger, U.: Heterogeneous chemical processing of ${ }^{13} \mathrm{NO}_{2}$ by monodisperse carbon aerosols at very low concentrations, J. Phys. Chem., 100, 15 487-15 493, 1996.

Kärcher, B. and Lohmann, U.: A parameterization of cirrus cloud formation: Heterogeneous freezing, J. Geophys. Res.-Atmos., 108, 4402, doi:10.1029/2002JD003220, 2003.

Keyser, L. F., Moore, S. B., and Leu, M. T.: Surface-Reaction and Pore Diffusion in Flow-Tube Reactors, J. Phys. Chem., 95, 54965502, 1991.

Krueger, B. J., Grassian, V. H., Cowin, J. P., and Laskin, A.: Heterogeneous chemistry of individual mineral dust particles from different dust source regions: the importance of particle mineralogy, Atmos. Environ., 38, 6253-6261, 2004.

Krueger, B. J., Grassian, V. H., Laskin, A., and Cowin, J. P.: The transformation of solid atmospheric particles into liquid droplets through heterogeneous chemistry: Laboratory insights into the processing of calcium containing mineral dust aerosol in the troposphere, Geophys. Res. Lett., 30, 1148, doi:10.1029/2002GL016563, 2003.

Laskin, A., Iedema, M. J., Ichkovich, A., Graber, E. R., Taraniuk, I., and Rudich, Y.: Direct observation of completely processed calcium carbonate dust particles, Faraday Discuss., 130, 453468, 2005.

Laskin, A., Wietsma, T. W., Krueger, B. J., and Grassian, V. H.: Heterogeneous chemistry of individual mineral dust particles with nitric acid: A combined CCSEM/EDX, ESEM, and ICP-MS study, J. Geopyhs. Res., 110, D10208, doi:10.1029/2004JD005206, 2005.

Lohmann, U., Karcher, B., and Hendricks, J.: Sensitivity studies of cirrus clouds formed by heterogeneous freezing in the ECHAM GCM, J. Geophys. Res.-Atmos., 109, D16204, doi:10.1029/2003JD004443, 2004.

Matsuki, A., Iwasaka, Y., Shi, G. Y., Zhang, D. Z., Trochkine, D., Yamada, M., Kim, Y. S., Chen, B., Nagatani, T., Miyazawa, T., Nagatani, M., and Nakata, H.: Morphological and chemi- 
cal modification of mineral dust: Observational insight into the heterogeneous uptake of acidic gases, Geophys. Res. Lett., 32, L22806, doi:10.1029/2005GL024176, 2005.

Maxwell-Meier, K., Weber, R., Song, C., Orsini, D., Ma, Y., Carmichael, G. R., and Streets, D. G.: Inorganic composition of fine particles in mixed mineral dust-pollution plumes observed from airborne measurements during ACE-Asia, J. Geophys. Res.-Atmos., 109, D19S07, doi:10.1029/2003JD004464, 2004.

Naumann, K. H.: COSIMA - a computer program simulating the dynamics of fractal aerosols, J. Aerosol. Sci., 34, 1371-1397, 2003.

Neuman, J. A., Huey, L. G., Ryerson, T. B., and Fahey, D. W.: Study of inlet materials for sampling atmospheric nitric acid, Environ. Sci. Technol., 33, 1133-1136, 1999.

Pöschl, U., Letzel, T., Schauer, C., and Niessner, R.: Interaction of ozone and water vapor with spark discharge soot aerosol particles coated with benzo[a]pyrene: $\mathrm{O}_{3}$ and $\mathrm{H}_{2} \mathrm{O}$ adsorption, benzo[a]pyrene degradation, and atmospheric implications, J. Phys. Chem. A, 105, 4029-4041, 2001.

Pöschl, U., Rudich, Y., and Ammann, M.: Kinetic model framework for aerosol and cloud surface chemistry and gas-particle interactions: Part 1 - general equations, parameters, and terminology, Atmos. Chem. Phys. Discuss., 5, 2111-2191, 2005, mboxhttp://www.atmos-chem-phys-discuss.net/5/2111/2005/.

Rogak, S. N., Baltensperger, U., and Flagan, R. C.: Measurement of mass transfer to agglomerate aerosols, Aerosol Sci. Technol., 14, 447-458, 1991.

Saathoff, H., Naumann, K. H., Schnaiter, M., Schock, W., Mohler, O., Schurath, U., Weingartner, E., Gysel, M., and Baltensperger, U.: Coating of soot and $\left(\mathrm{NH}_{4}\right)_{2} \mathrm{SO}_{4}$ particles by ozonolysis products of alpha-pinene, J. Aerosol. Sci., 34, 1297-1321, 2003.

Sassen, K., DeMott, P. J., Prospero, J. M., and Poellot, M. R.: Saharan dust storms and indirect aerosol effects on clouds: CRYSTAL-FACE results, Geophys. Res. Lett., 30, 1633, doi:10.1029/2003GL017371, 2003.

Schott, J. and Oelkers, E. H.: Dissolution and Crystallization Rates of Silicate Minerals as a Function of Chemical Affinity, Pure Appl. Chem., 67, 903-910, 1995.

Seinfeld, J. H., Carmichael, G. R., Arimoto, R., Conant, W. C., Brechtel, F. J., Bates, T. S., Cahill, T. A., Clarke, A. D., Doherty, S. J., Flatau, P. J., Huebert, B. J., Kim, J., Markowicz, K. M., Quinn, P. K., Russell, L. M., Russell, P. B., Shimizu, A., Shinozuka, Y., Song, C. H., Tang, Y. H., Uno, I., Vogelmann, A. M., Weber, R. J., Woo, J. H., and Zhang, X. Y.: ACE-ASIA - Regional climatic and atmospheric chemical effects of Asian dust and pollution, Bull. Amer. Meteorol. Soc., 85, 367-380, 2004.

Seisel, S., Börensen, C., Vogt R., and Zellner, R.: The heterogeneous reaction of $\mathrm{HNO}_{3}$ on mineral dust and gamma-alumina surfaces: a combined Knudsen cell and DRIFTS study, Phys. Chem. Chem. Phys., 6, 498-5508, 2004.
Sumner, A. L., Menke, E. J., Dubowski, Y., Newberg, J. T., Penner, R. M., Hemminger, J. C., Wingen, L. M., Brauers, T., and Finlayson-Pitts, B. J.: The nature of water on surfaces of laboratory systems and implications for heterogeneous chemistry in the troposphere, Phys. Chem. Chem. Phys., 6, 604-613, 2004.

Tang, I. N. and Fung, K. H.: Hydration and Raman scattering studies of levitated microparticles: $\mathrm{Ba}\left(\mathrm{NO}_{3}\right)_{2}, \mathrm{Sr}\left(\mathrm{NO}_{3}\right)_{2}$, and $\mathrm{Ca}\left(\mathrm{NO}_{3}\right)_{2}$, J. Chem. Phys., 106, 1653-1660, 1997.

Tang, Y. H., Carmichael, G. R., Kurata, G., Uno, I., Weber, R. J., Song, C. H., Guttikunda, S. K., Woo, J. H., Streets, D. G., Wei, C., Clarke, A. D., Huebert, B., and Anderson, T. L.: Impacts of dust on regional tropospheric chemistry during the ACE-Asia experiment: A model study with observations, J. Geophys. Res.Atmos., 109, D19S21, doi:10.1029/2003JD003806, 2004.

Umann, B., Arnold, F., Schaal, C., Hanke, M., Uecker, J., Aufmhoff, H., Balkanski, Y., and Van Dingenen, R.: Interaction of mineral dust with gas phase nitric acid and sulfur dioxide during the MINATROC II field campaign: First estimate of the uptake coefficient gamma $\left(\mathrm{HNO}_{3}\right)$ from atmospheric data, J. Geophys. Res.-Atmos., 110, D22306, doi:10.1029/2005JD005906, 2005.

Underwood, G. M., Song, C. H., Phadnis, M., Carmichael, G. R., and Grassian, V. H.: Heterogeneous reactions of $\mathrm{NO}_{2}$ and $\mathrm{HNO}_{3}$ on oxides and mineral dust: A combined laboratory and modeling study, J. Geophys. Res.-Atmos., 106, 18 055-18 066, 2001.

Underwood, G. M., Li, P., Usher, C. R., and Grassian, V. H.: Determining Accurate Kinetic Parameters of Potentially Important Heterogeneous Atmospheric Reactions on Solid Particle Surfaces with a Knudsen Cell Reactor, J. Chem. Phys., 104, 819829, 2000.

Usher, C. R., Michel, A. E., and Grassian, V. H.: Reactions on Mineral Dust, Chem. Rev., 103, 4883-4939, 2003.

Vlasenko, A., Sjogren, S., Weingartner, E., Gäggeler, H. W., and Ammann, M.: Generation of submicron Arizona test dust aerosol: Chemical and hygroscopic properties, Aerosol Sci. Technol., 39, 452-460, 2005.

Weingartner, E., Gysel, M., and Baltensperger, U.: Hygroscopicity of aerosol particles at low temperatures. 1. New low-temperature H-TDMA instrument: Setup and first applications, Environ. Sci. Technol., 36, 55-62, 2002.

Xiong, Y., Pratsinis, S. E., and Weimer, A. W.: Modeling the Formation of Boron-Carbide Particles in an Aerosol Flow Reactor, Aiche J., 38, 1685-1692, 1992. 